\title{
"SINDEN BERTAPA" METODE MENUJU TERTIB ADMINIDTRASI BIDANG PERTANAHAN (STUDI DI DESA TRISARI KECAMATAN GUBUG KABUPATEN GROBOGAN)
}

\author{
Ana Silviana, Mira Novana Ardani \\ Fakultas Hukum Universitas Diponegoro \\ J1. Prof. Soedarto,SH. Tembalang, Semarang \\ silvianafhundip@gmail.com
}

\begin{abstract}
The administrative order of the land affairs is the main policy of land in order to realize the complete data of each registered land plot and is known easily, both regarding history, ownership, subject of rights, physical condition and procedural order in any matters concerning land excavating land registration. The purpose of this study is to examine and analyze the "Sinden Bertapa" which can be a method toward the Administration of Land Affairs. The approach method in this research is empirical juridical, using secondary data and primary data. The result of the research is "Sinden Bertapa" is a participatory mapping product that can realize the Order of Land Administration as the initial data in order to help the land registration program through PTSL to build One Map Policy
\end{abstract}

Keyword : The Administration of Land Affairs, Sinden Bertapa, One Map Policy

\begin{abstract}
Abstrak
Tertib administrasi bidang pertanahan merupakan kebijakan pokok pertanahan dalam rangka untuk mewujudkan kelengkapan data dari setiap bidang tanah tercatat dan diketahui dengan mudah, baik mengenai riwayat, kepemilikan, subjek haknya, keadaan fisik serta ketertiban prosedur dalam setiap urusan yang menyangkut tanah melali pendaftaran tanah. Tujuan penelitian ini adalah untuk mengkaji dan menganalisis tentang "Sinden Bertapa" yang dapat menjadi metode menuju Tertib Administrasi Bidang Pertanahan. Metode pendekatan dalam penelitian ini adalah yuridis empiris, dengan menggunakan data sekunder dan data primer. Hasil penelitian adalah "Sinden Bertapa" merupakan produk pemetaan partisipatif yang dapat mewujudkan Tertib Adminitrasi Pertanahan sebagai data awal dalam rangka membantu program pendaftaran tanah melalui PTSL untuk membangun One Map Policy.
\end{abstract}

Kata Kunci : Tertib Administrasi Pertanahan, Sinden Bertapa, One Map Policy

\section{A. Pendahuluan}

Tanah bagi kehidupan bangsa

Indonesia masih berperan penting, karena tanah merupakan sarana bagi tempat hidup dan penghidupannya. Peran Negara dalam pengelolaan tanah di Indonesia menjadi sangat penting agar tidak terjadi benturan penguasaan dan pengelolaan tanah antar masyarakat maupun masyarakat dengan Pengusaha, atau dengan Pemerintah dalam pemanfaatan tanah tersebut. Hal ini dalam rangka mewujudkan tanah untuk sebesar- 
besar kemakmuran rakyat sebagaimana diamanatkan dalam Pasal 33 ayat (3) Undang-Undang Dasar Negara Republik Indonesia Tahun 1945 sebagai landasan politik agraria Indonesia.

Pengaturan dan pengelolaan tanah untuk sebesar-besar kemakmuran rakyat, adalah suatu kebijakan yang masuk dalam ranah adminsitrasi pertanahan. Administrasi Pertanahan adalah suatu usaha dan manajemen yang berkaitan dengan penyelengaraan kebijaksanaan pemerintah di bidang pertanahan dengan mengerahkan sumber daya untuk mencapai tujuan sesuai dengan ketentuan perundang-undangan yang berlaku (Murad, 1997). Dari definisi tersebut dapat dikatakan bahwa, administrasi pertanahan merupakan bagian dari administrasi pemerintahan yang dalam penyelenggara kebijaksanaan di bidang pertanahan tersebut, yang pelaksanaannya dilakukan oleh Badan Pertanahan Nasional.

Tertib Administrasi bidang Pertanahan merupakan salah satu sasaran dari Catur Tertib Pertanahan yang ditentukan dalam Tap MPR Nomor IV/MPR/2978 sebagai dijadikan landasan dan sekaligus sasaran untuk mengadakan penataan kembali penggunaan dan pemilikan tanah serta program-progran di bidang pertanahan dalam rangka terwujudnya tanah untuk kesejahteraan dan keadilan rakyat Indonesia (Alamsah, 2012). Tertib adminitrasi pertanahan dapat terwujud dengan dilaksanakannya pendaftaran tanah, sehingga setiap bidang tanah telah tersedia catatan mengenai aspek-aspek ukuran fisik, penguasaan, penggunaan, jenis hak dan kepastian hukumnya, yang dikelola dalam sistem informasi pertanahan yang lengkap.

Tujuan pendaftaran tanah sebagaimana diamanatkan oleh UUPA - payung hukum perftanahan di Indonesia - adalah memberikan jaminan kepastian hukum dan perlindungan hukum terhadap hak atas tanah dan kepemilikan tanah (Harsono, 2010). Namun, sampai sekarang belum terwujud, karena munculnya kendala-kendala dalam pelaksanaannya, antara lain kendala untuk menyediakan informasi kepada pihak-pihak yang berkepentingan dan kendala terwujudnya tertib administrasi pertanahan. Hal tersebut muncul karena masih terbatasnya sumber daya manusia dalam melaksanakan kegiatan pendaftaran tanah.

Terbatasnya sistem informasi bidang pertanahan di Kantor Pertanahan selama ini sehingga sangat menghambat pelayanan kepada masyarakat yang akan melalukan perbuatan hukum dengan tanah yang bersangkutan. Munculnya sertipikat ganda, sengketa batas dan sengketa kepemilikan, terjadi karena terbatasnya informasi bidang pertanahan di Kantor Pertanahan dan belum terpetakannya bidang-bidang tanah yang 
sudah terdaftar dalam satu peta (Soeradji dan Nyoman Guntur, 2007).

Masih tingginya posisi kasus pertanahan yang melibatkan sesama/antar anggota masyarakat sebesar $71,45 \%$, yang secara detail melibatkan orang perorangan mencapai $36,85 \%$, kondisi ini mengindikasikan bahwa persoalan kesejahteraan masyarakat dan ketergantungan hidup masyarakat terhadap tanah masih sangat tinggi (BAPPENAS, 2016). Kepastian hukum hak atas tanah merupakan masalah yang belum terselesaikan. Berdasarkan kondisi ini, diperlukan berbagai strategi pengelolaan pertanahan yang berorientasi pada peningkatan kesejahteraan masyarakat melalui keadilan penguasaan dan pemilikan tanah serta pemberian kepastian hukum hak atas tanah secara kuat.

Kebijakan satu peta / One Map Policy (OMP), sebagai salah satu Paket Kebijakan Ekonomi VIII bertujuan untuk menyamakan persepsi semua pihak dalam memandang ruang kebumian. OMP ini akan mempermudah dan mempercepat penyelesaian konflik tumpang tindih pemanfaatan lahan, penyelesaian batas daerah seluruh Idonesia. Terkait dengan penerapan OMP, Pemerintah dalam Nawa Cita ke III bertekad akan membangun Indonesia dari pinggirian dengan memperkuat daerah-daerah dan desa dalam kerangka negara kesatuan.

Di bidang pertanahan, layanan administrasi pertanahan merupakan bentuk komitmen agar pertanahan didasarkan atas data yang valid dan akurat. Untuk mendukung tersedianya data yang valid serta akurat tersebut, harus dibangun dan diterapkan kebijakan satu peta (OMP). Konflik pertanahan yang sering terjadi disebabkan juga oleh pengadministrasian pertanahan yang dilakukan selama ini belum tertib dan belum selaras. Untuk segera menuju ke arah Pemetaan Lengkap (OMP) yang berbasis tanah ternyata masih banyak kendala, yaitu diperlukan sumber dana yang besar, terbatasnya jumlah SDM, adanya ego sektoral, cakupan wilayah yang luas, dan peta-peta dasar belum tersedia.

Kantor Pertanahan Kabupaten Grobogan telah melakukan suatu terobosan baru melalui metode pemetaan partisipatif guna mempercepat terwujudnya pelaksanaan kebijakan satu peta, yaitu melalui Sistem Informasi Desa/Kelurahan Berbasis Pemetaan Partisipatif (SINDEN BERTAPA). Metode ini bertujuan untuk menyamakan persepsi semua pihak dalam memandang ruang kebumian, melalui pemetaan partisipatif, yaitu metode pemetaan yang menempatkan masyarakat/stakeholder sebagai bagian dari salah satu atau keseluruhan proses 
pembuatan peta, baik dari segi perencanaan, pelaksanaan, maupun pembiayaan (Fahmi, 2016). Data yang dihasilkan dari "SINDEN BERTAPA" diharapkan dapat mempercepat perolehan data tanah melalui program Pendaftaran Tanah Sistematis Lengkap (PTSL) yang sedang digalakkan oleh BPN, dengan data awal dari Desa/Kelurahan yang sudah terpetakan lengkap melalui "SINDEN BERTAPA". Desa Trisari, Kecamatan Gubug, Kabupaten Grobogan, merupakan salah satu desa dari seluruh desa di wilayah Kabupaten Grobogan yang sudah selesai melakukan program pemetaan partisipatif melalui metode "SINDEN BERTAPA", sebagai sosial setting dalam penelitian ini.

Dari uraian di atas maka permasalahan yang dikaji dalam penelitian ini adalah sebagai berikut:

1. Bagaimana mekanisme pelaksanaan "Sinden Bertapa" di Desa Trisari Kecamatan Gubug, Kabupaten Grobogan terkait dengan Pendaftaran Tanah Sistematik Lengkap (PTSL)?

2. Bagaimana membangun sistem informasi dalam mewujudkan One Map Policy menuju Tertib Administrasi Pertanahan?

\section{B. Metode Penelitian}

Metode pendekatan dalam penelitian ini adalah yuridis empiris/sosiologis untuk memperdalam dan memperluas obyek yang diteliti, karena dalam penelitian ini akan dilihat bagaimana bekerjanya hukum dalam masyarakat dan bagaimana hukum berinteraksi dengan masyarakat. Dengan demikian dalam penelitian ini di samping akan dikaji secara teori (law in book), juga dikaji bagaimana yang terjadi di masyarakat (law in action), dengan kata lain hukum tidak hanya dilihat sebagai suatu entitas normatif yang mandiri atau isoterik, melainkan justru harus dilihat sebagai bagian riil dari sistim sosial yang berkaitan dengan variable social yang lain (Soekanto, 1988). Metode "SINDEN BERTAPA" menuju tertib administrasi bidang pertanahan, di Desa Trisari, Kecamatan Gubug, Kabupaten Grobogan perlu diteliti dari aspek-aspek hukumnya juga realitas empiriknya dalam masyarakat yang melelakukan kegiatan pemetaan partisipatif. Oleh karena itu, dalam penelitian ini di samping akan dikaji secara teori (law in book), juga dikaji bagaimana yang terjadi di masyarakat (law in action

Penelitian ini menggunakan data primer yang dihimpun dari penelitian lapangan dengan informan dan narasumber, dan data sekunder dari penelitian kepustakaan melalui bahan-bahan hukum. Data dari hasil penelitian lapangan dan penelitian kepustakaan terkumpul, kemudian dilakukan suatu analisa melalui analisis kualitatif untuk menjawab permasalahan 
dalam penelitian ini dengan menarik kesimpulan secara induktif.

\section{Hasil dan Pembahasan}

1. Mekanisme "Sinden Bertapa" di Desa Trisari Kecamatan Gubug, Kabupaten Grobogan dan pelaksanaan Pendaftaran Tanah Sistematik Lengkap (PTSL).

a. Mekanisme "Sinden Bertapa" di Desa Trisari Kecamatan Gubug, Kabupaten Grobogan

Kebijakan satu peta (OMP) akan mengacu pada satu referensi geospasial, satu standar, satu basis data dan satu geoportal untuk mempercepat pelaksanaan pembangunan nasional menjadi salah satu prioritas pemerintah. Berbasis pada referensi peta yang sama, maka akan meningkatkan juga keandalan informasi terkait lokasi dari berbagai aktivitas ekonomi. Hal ini akan memberikan kepastian dalam usaha. Berbagai informasi yang dikompilasi dalam satu peta juga dapat dimanfaatkan untuk sejumlah simulasi, antara lain untuk mitigasi bencana (Bappenas, 2016).

Dibidang Pertanahan perwujudan Tertib Administrasi Pertanahan masih dipersimpangan jalan karena masih banyaknya permasalahan yang muncul terkait dengan sengketa kepemilikan tanah dan sengketa duplikasi alat bukti kepemilikan tanah. Untuk meningkatkan kualitas dan kuantitas database pertanahan maka harus selalu dilakukan pembuatan dan updating data untuk mendapatkan data yang akurat dan terkini. Namun kenyataannya ada permasalahanpermasalahan yang di hadapi, antara lain: 1) Diperlukan sumber dana yang besar: 2). Terbatasnya jumlah Sumber Daya Manusia; dan 3). Cakupan Wilayah yang luas: 4). Peta-peta persil belum tersedia secara lengkap (Fahmi, 2016).

Salah satu solusi yang dilakukan adalah dengan mengadakan kegiatan Pemetaan Partisipatif yang dilakukan bersama-sama dengan pihak lain, yaitu metode pemetaan yang menempatkan masyarakat / stakeholder sebagai bagian dari salah satu atau keseluruhan proses pembuatan peta, baik dari segi perencanaan, pelaksanaan maupun pembiayaan. Kegiatan Pemetaan Partisipatif sudah mulai dilaksanakan di Kabupaten Grobogan oleh Kantor Pertanahan Kabupaten Grobogan, dengan membangun Sistem Informasi Desa dan Kelurahan Berbasis Peta Partisipatif (SINDEN BERTAPA).

Bentuk partisipasi tersebut datang dari pihak Pemerintah Kabupaten yaitu dengan tugas mengkoordinasi wilayah, Pengarahan Kegiatan dan Anggaran, Penyedia Anggaran khusus untuk kelurahan. Pihak BPN melakukan perencanaan, Kontrol Kualitas, Peta Citra, Peta Pendaftaran dan 
data Pertanahan lainnya (sesuai ketentuan yang berlaku). Dari pihak Desa menyediakan anggaran, informasi dan membantu pelaksanaan, sedangkan dari pihak Swasta sebagai pelaksana kegiatan dan pertanggungjawaban Administrasi dan Keuangan (Fahmi, 2016).

Ide program "Sinden Bertapa" diluncurkan oleh Mansur Fahmi,SsiT, pada waktu itu sebagai Kasubsi Tematik dan Potensi Tanah Kantor Pertanahan Kabupaten Grobogan (sekarang beliau pindah tugas di Kantor Wilayah Badan Pertanahan Nasional Propinsi Jawa Tengah). Menurut Fahmi maksud dan tujuan dari kegiatan "Sinden Bertapa" adalah sebagai upaya percepatan pembangunan data spasial yang berkualitas di Kabupaten Grobogan menuju terwujudnya kebijakan satu peta (one map policy) melalui pembuatan peta desa/kelurahan berbasis bidang tanah yang dilaksanakan secara terpadu antara Pemerintah Kabupaten Grobogan, Kantor Pertanahan Kabupaten Grobogan, Pemerintah Kecamatan, Pemerintah Desa / Kelurahan dan pihak swasta.

\section{Desa Trisari Kecamatan Gubug}

Kabupaten Grobogan adalah salah satu desa dari 21 desa di wilayah Kecamatan Gubug yang juga telah selesai melaksanakan "Sinden Bertapa". Namun kondisi sekarang hasilnya belum maksimal, demikian informasi dari Carik (Sekretaris Desa)
Trisari. Hal ini penyebabnya adalah karena data yang diperoleh dari "Sinden Bertapa" belum ter-input di data visual (komputer). Kendala utama di Desa Trisari adalah kemampuan SDM perangkat Desa yang masih belum ada dalam bidang Internet Teknologi (IT), sehingga data "Sinden Bertapa" masih manual, belum ter input dalam komputer sehingga belum ada out put data dalam jaringan internet website desa.

Pelaksanaan "Sinden Bertapa" menurut Fahmi sebagai narasumber dalam penelitian ini dan sebagai penggagas metode "Sinden Bertapa", dibutuhkan tersedianya : 1) Peta Citra yang digunakan sebagai Peta Dasar adalah Peta Citra yang digunakan oleh Kantor Pertanahan Kabupaten Grobogan, karena dimungkinkan ada Peta Citra yang lain, misalkan dari Kehutanan atau dari Pemerintah; 2) Peta Pendaftaran Kantor Pertanahan dijadikan Peta Kerja sebagai acuan awal kegiatan; 3) Teknik pembuatan peta menggunakan prinsip-prinsip kartografik; 4) Pelaksana kegiatan adalah tenaga terdidik di bidang pemetaan. Peta Citra merupakan media yang dapat digunakan sebagai Peta Dasar kegiatan "Sinden Bertapa". Peta Satelit yang dipergunakan dalam "Sinden Bertapa" adalah Peta Satelit Kantor Pertanahan dalam hal ini Kantor Pertanahan Kabupaten Grobogan, dengan tujuan agar lebih mudah, 
sinkron dan terpadu dengan Peta Pendaftaran Tanah di Kantor Pertanahan.

Terwujudnya "Sinden Bertapa" ini adalah karena adanya kerjasama yang baik dari berbagai pihak, dimana masing-masing pihak berpastisipasi dan berkontribusi sesuai dengan kapasitas, para pihak tersebut yaitu: Pemerintah Kabupaten/Kota dan Pemerintah Kecamatan, Kantor Pertanahan Kabupaten/Kota, Pemerintah Kelurahan, Pemerintah Desa, dan Swasta (Fahmi, 2016). Kabupaten Grobogan juga membuat suatu kebijakan Pemetaan Batas Wilayah. Kebijakan ini adalah dalam rangka untuk membangun batas wilayah baik batas daerah maupun batas nasional dalam rangka untuk menghasilkan kedaulatan batas wilayah dan mengurangi konflik batas wilayah antar daerah. Pemerintah Daerah melalui Bappeda melakukan pendekatan dan merangkul dengan setiap instansi lain untuk bekerja sama dalam rangka mewujudkan batas daerah yang baik, akurat dan dapat dijadikan patokan dasar untuk pengambilan kebijakan di masa yang akan datang. Up date batas harus dimulai dari unit pemetaan paling kecil dari mulai desa/kelurahan. Kegiatan Pemetaan Batas Wilayah ini juga dalam rangka untuk memperbaiki peta batas wilayah Kabupaten Grobogan sesuai dengan kenyataan di lapangan, melalui pembuatan peta batas desa/kelurahan, kecamatan dan kabupaten. Hasil peta batas wilayah berupa peta batas wilayah desa, peta batas wilayah kecamatan, dan peta batas wilayah kabupaten. Pada akhirnya, nantinya diharapkan Peta Geo Data, Sinden Bertapa, Peta Citra dapat terintegrasi sebagai acuan untuk pengambilan kebijakan lebih lanjut untuk semua instansi dan pemerintah daerah Kabupaten Grobogan.

Proses "Sinden Bertapa" di Desa Trisari melibatkan berbagai pihak yaitu Pemerintah Daerah Kabupaten Grobogan dalam hal ini Pemerintah Kecamatan Gubug mendorong dan mengkoordinir desa untuk memasukkan kegiatan pembuatan peta desa di dalam Anggaran Desa. Mengkondisikan agar dalam pelaksanaan pemetaan dapat berjalan lancar, serta memberi bimbingan dalam pembuatan pelaporan keuangan Desa Trisari. Pihak Kantor Pertanahan Kabupaten Grobogan dalam kegiatan ini bertugas untuk merencanakan arah kegiatan pemetaan dan menentukan standar kualitas, menyediakan Peta Citra dan data pertanahan lainnya sepanjang tidak bertentangan dengan ketentuan yang berlaku di bidang pendaftaran tanah. Melaksanakan pendampingan, bimbingan dan arahan agar dalam pelaksanaan pemetaan dapat berjalan dengan baik dan lancar. Di sini tugas utama adalah dibidang kontrol kualitas.

Pihak Pemerintah Desa Trisari dalam pelaksanaan "Sinden Bertapa" menurut Mahmudi sebagai Carik/Sskretaris Desa 
Trisari yaitu menyediakan anggaran, yang diambil dari Alokasi Dana Desa sebesar Rp. 9.000.000,- (sembilan Juta rupiah). Desa Trisari menentukan pihak konsultan yang melaksanakan kegiatan pemetaan yaitu dari Fakultas Planologi Universitas Gadjah Mada Yogyakarta. Pemetaan partisipatif yang dilaksanakan di Desa Trisari adalah bekerja sama dengan pihak swasta. Kegiatan terakhir adalah membuat pertanggungjawaban keuangan dalam penggunaan anggaran.

Pihak swasta sebagai pelaksana lapangan bertugas untuk melakukan kegiatan pemetaan meliputi: perencanaan, persiapan, survey lapangan, pembuatan sistem informasi, pelatihan perangkat desa. Memberikan hasil pekerjaan kepada Pemerintah Kabupaten, Desa dan Kantor Pertanahan Kabupaten Grobogan. Pihak swasta yang digandeng dalam kegiatan "Sinden Bertapa" adalah CV Geo Data Yogyakarta.

Pelaksanaan "Sinden Bertapa" bahan awal yang dipergunakan dalam pembuatan peta batas desa adalah Peta Citra dari Kantor Pertanahan Kabupaten Grobogan. Metode yang dipergunakan adalah melibatkan Perangkat Desa untuk mewarnai batas-batas desanya sendiri dengan 3 (tiga) warna spidol, yaitu batas desa dan jalan desa diberi warna Merah dalam Peta Citra tersebut, Warna Hijau untuk sungai, saluran air yang ada dan warna Kuning menunjukkan tanahtanah Kas Desa. Kegiatan Sinden Bertapa dilakukan dalam empat tahap.

Kegiatan Tahap I telah dilakukan pada tahun 2014, yaitu pembuatan Peta Dasar Berbasis Desa untuk 280 Desa se Kabupaten Grobogan. Hasilnya adalah terwujudnya Peta Dasar berbasis desa yang cukup lengkap, dapat memberi informasi batas desa, jaringan jalan, sungai tempattempat penting seperti kantor pemerintahaan, fasilitas pendidikan, fasilitas kesehatan, sebaran tanah kas desa dan lainlain. Peta Dasar se Kabupaten Grobogan telah tercapai sebanyak 280 Desa/Kelurahan berupa soft copy maupun hard copy berupa album perta dengan anggaran Rp.49.400.000,- (empat pulu sembilan juta empat ratus ribu rupiah).

Tahap II (Tahun 2015-2017) sebagai tindak lanjut dari kegiatan Tahap I, yaitu pembuatan Peta Desa Digital Berbasis Bidang Tanah. Target pada tahap ini adalah dibangunnya peta desa berbasis bidang tanah yang memuat informasi nama pemilik tanah, batas wilayah: batas desa, batas dusun, penggunaan tanah, dan lain-lain. Peta yang dipergunakan untuk kerja dilapangan adalah menggunakan Peta Geo KKP yang disusun di atas Peta Citra kemudian dikompilasikan dengan Peta PBB (Kabupaten Grobogan baru tersedia 45\% Peta PBB). Untuk melengkapi data dengan 
mendeliniasi di atas Peta Citra berdasarkan hasil survei dan informasi dari perangkat desa maupun masyarakat. Hasil dari kegiatan ini adalah Album Peta Desa (dalam bentuk Hard copy) dan "Sinden Bertapa". Sampai akhir September 2016 sudah terselesaiakn di 150 desa di Kabupaten Grobogan. "Sinden Bertapa" merupakan produk dari kegiatan pemetaan yang melibatkan berbagai pihak. Metode dan produk "Sinden Bertapa" adalah kemauan desa, demikian kata Fahmi sebagai narasumber dalam penelitian ini. Kemauan desa karena Desa mengalokasikan sebagain dana desa untuk kegiatan ini, dan desa juga mengalokasikan sebagain tenaga, waktu untuk kegiatan ini.

Tahap III ( Tahun 2016-2020 ) dilakukan Pembuatan Peta-Peta Tematik, GIM, Nomor SPPT, Pemasangan Tugu Batas. Metode yang dilakukan adalah dengan penghimpunan data sosial kepada masyarakat pemilik tanah dengan membagikan kuesioner yang berisi pertanyaan-pertanyaan antara lain: nama pemilik tanah, status tanah yang sudah bersertipikat atau yang belum, nomor sertipikat apabila sudah bersertipikat, Nomnor SPPT, harga tanah,tingkat pendidikan, jumlah pendapatan rata-rata perbulan, penggunaan tanah (pertanian/non pertanian), apabila tanah sawah maka apakah sawah irigasi atau sawah non teknis, berapa kali panen dalam setahun, dan lainlain informasi yang diperlukan. Dapat juga dilengkapi dengan data visual berupa foto atau film. Data ini kemudian dimasukkan dalam "Sinden Bertapa", yang akan digunakan oleh desa/kelurahan dan pihakpihak terkait untuk berbagai keperluan. Batas wilayah dapat dibetulkan dan diujudkan dalam bentuk peta yang dilanjutkan dengan Penetapan dan Penegasan Batas Desa yang ditandai dengan pemasangan TUGU BATAS, harapannya batas wilayah yang dipetakan sampai batas dusun. Akhirnya, harapan dengan berhasilnya kegiatan pemetaan dusun demi dusun dalam satu desa secara benar, maka akan mengurangi potensi konflik. Desa Trisari sudah lengkap dalam tahap ke III ini.

$$
\text { Tahap IV (Tahun } 2017 \text { - 2020) }
$$

adalah Pembuatan Web GIS, PemasanganTugu Batas Bidang Tanah. Tahap ini sedang berjalan, namun untuk Desa Trisari berhenti, karena terkendala tidak adanya SDM di desa yang dapat input data ke komputerisasi. Pada tahun 2020 target yang diharapkan dari kegiatan ini adalah terkoneksinya data antar instansi menuju kebijakan SATU PETA NASIONAL (One Map Policy).

Peta partisipatif "Sinden Bertapa" ini bersifat peta tumbuh/bertahap. Pembuatan dan pengembangan Peta Desa ini mengacu kepada tahapan kegiatan yang telah umum 
pada pengembangan sistem informasi goegrafis yaitu penyempurnaan dari model "water fall". Model penyempurnaan water fall ini dilakukan secara bertahap dari awal hingga akhir. Sebagai contoh: Tahap III hanya dapat dilakukan apabila Tahap II telah dilakukan dan hasil tersebut telah disetujui dan memenuhi kebutuhan dari pihak pengguna. Berlanjut dengan tahapan selanjutnya. Dengan model penyempurnaan dari water fall model, maka pada setiap tahapan dapat dilakukan penyempurnaan dan koreksi pada tahapan sebelumnya untuk mendapatkan hasil yang maksimal demikian kata Fahmi.

Kondisi terkini berdasarkan hasil penelitian di Desa Trisari, "Sinden Bertapa" masih tersedia hanya sebagai berkas, data tertulis lengkap yang belum ter input dalam data komputrisasi. Kendala utama adalah tidak tersedianya SDM yang memadaai untuk dapat meng-input data ke komputerisasi. Hal ini yang sangat disayangkan, karena segala sesuatu hal meskipun produk baik, namun apabila penerapannya tidak maksimal maka belum dapat dimanfaatkan merupakan hal yang siasia. Data tersebut masih tersimpan sebagai hard copy di Kantor Desa Trisari Kecamatan Gabus Kabupaten Grogogan.

\section{b. Manfaat "Sinden Bertapa" dalam Pelaksanaan Peningkatan Kualitas}

\section{dan Kuantitas Data Pertanahan melalui PTSL.}

Kegiatan pemetaan partisipatif "sinden bertapa" merupakan kerja kolaboratif yang melibatkan stake holder Kantor Pertanahan Kabupaten/Kota, Pemerintah Kabupaten/Kota, Desa/Kelurahan, perangkat desa dan masyarakat langsung serta pihak swasta. Awalnya memang kegiatan "sinden bertapa" ini tidak mengarah kepada kegiatan yang sekarang dilancarkan oleh Pemerintah dalam rangka percepatan pendaftaran tanah melalui Pendaftaran Tanah Sistematik Lengkap (PTSL), karena tujuan utama hanya mendapatkan kualitas data dengan peta desa lengkap dengan data lengkap spasial dan data sosial masing-masing desa/kelurahan. Namun kemungkinan ke depan dapat disinergikan dengan program PTSL dengan dasar peta desa yang sudah lengkap menuju sertipikasi tanah.

Pemetaan Partisipatif melalui metode "sinden bertapa" merupakan kegiatan yang dilaksanakan dari bawah yaitu desa dengan dana yang didanai oleh Desa dengan hasil akhir adalah peta desa yang lengkap dengan data sosialnya. Kegiatan PTSL adalah program dari Badan Pertanahan Nasional dalam rangka untuk mempercepat terwujudkan target 5 (lima) juta bidang tanah tersertifikasi di tahun 2017 dan 7 (tujuh) juta bidang tanah untuk Tahun 2018. Pendanaan PTSL bersumber dari APBN. 
Objek PTSL meliputi seluruh bidang tanah tanpa terkecuali, baik bidang tanah hak, tanah aset Pemerintah/Pemerintah Daerah, tanah Badan Usaha Milik Negara/Badan Usaha Milik Daerah, tanah desa, Tanah Negara, tanah masyarakat hukum adat, kawasan hutan, tanah obyek landreform, tanah transmigrasi, dan bidang tanah lainnya. (Pasal 3 Peraturan Menteri Agraria dan Tata Ruang/Kepala Badan Pertanahan Nasional Nomor 1 Tahun 2017).

Mekanisme PTSL tidak lagi penunjukan secara sporadis bidang tanah yang akan didaftar, namun sudah mengarah ke lengkap, yaitu 1 (satu) Desa terpetakan semua dan terdaftar semua (Pendaftaran Tanah Desa demi Desa). Peta desa yang akurat dengan melalui "sinden bertapa" tentunya akan sangat membantu dalam kegiatan PTSL. Tentunya satu Desa sudah ada yang bersertipikat ada juga yang belum, misalnya desa Trisari sudah terbit 2000 sertipikat hal ini data masih ada di Peta Pendaftaran di Kantor Pertanahan dan belum "landing" di bidang tanahnya. Sebagian "melayang-layang" belum menempel pada tempat yang sebenarnya atau belum tepat pada bidang yang sebenarnya. Apabila Peta Desa sudah tersedia hal ini akan membantu pelaksanaan PTSL, sehingga munculnya masalah sertipikat ganda dapat diminimalisir.
Identifikasi awal bisa dilaksanakan sebelum PTSL dilaksanakan melalui data Peta Partisipatif Desa / "Sinden Bertapa". Bidang tanah mana yang bermasalah, mana yang dapat diterbitkan sertipikat, mana yang sebenarnya secara objek ada bidang tanahnya tetapi orang atau pemiliknya tidak ada akan dapat terdeteksi dengan benar, selanjutnya baru dilakukan dengan sertipikasinya. "Sinden Bertapa" ini memang belum sampai pengukuran. Kegiatan PTSL adalah tindak lanjutnya yaitu ditingkatkan dengan pengukuran oleh Kantor Pertanahan sebagai data sertipikasi tanah. Menurut pendapat narasumber kegiatan "sinden bertapa" ini belum dapat diterapkan ke dalam kegiatan PTSL, namun menurut pendapat penulis hal demikian sudah dapat disinergikan dengan pelaksanaan PTSL, khusus untuk desa yang sudah mempunyai Peta Partisipatif Desa/Kelurahan.

Kegiatan "sinden bertapa" rencananya baru dapat dikaitkan dengan kegiatan PTSL mulai pada tahun 2018. Untuk desa Trisari, pelaksanaan pemetaan partisipatif berjalan lancar tanpa hambatan, hanya yang menjadi kendala sekarang adalah belum adanya SDM yang dapat melakukan input data ke komputer, sehingga data "sinden bertapa" masih tersimpan dalam bentuk berkas di Kantor Kepala Desa. Hambatan yang muncul yang perlu dipikirkan setelah peta 
jadi, adalah mengenai proses pemeliharaan datanya bagaimana, karena peta bersifat dinamis, ada penggabungan dan pemecahan bidang, dan sampai saat ini belum ada kebijakan yang mengatur tentang bagaimana pemeliharaannya. Pemerintah Daerah segera harus menetapkan kebijakan dalam pemeliharaan data "Sinden Bertapa"

\section{Membangun Sistem Informasi dalam Mewujudkan One Map Policy Menuju Tertib Administrasi Pertanahan.}

Dalam rangka untuk membangun sistem informasi untuk mewujudkan satu peta Pendaftaran Tanah terkait dengan tiga elemen Sistem Hukum dari Friedman yaitu Substansi Hukum (Legal Substance), Struktur Hukum (Legal Structure) dan Budaya Hukum (Legal Culture) ( Saleh HS. dkk, 2009).

Dalam penataan terhadap substansi hukum bahwa tujuan dari pendaftaran tanah adalah dalam rangka memberikann jaminan kepastian hukum (rechts cadastre) hak atas tanah dan perlindungan hukum kepada pemegang atau pemilik hak atas tanah sebagaimana ditentukan dalam Pasal 19 UUPA dengan peraturan pelaksanaannya. Tujuan akan kepastian hukum dan perlindungan hukum dalam kepemilikan tanah akan terwujud apabila Administrasi bidang Pertanahan sudah tertata dengan rapi dan tertib.

Pengertian Administrasi Pertanahan adalah suatu usaha dan manajemen yang berkaitan dengan penyelenggaraan kebijaksanaan pemerintah dibidang pertanahan dengan mengerahkan sumber daya untuk mencapai tujuan sesuai dengan ketentuan perundang-undangan yang berlaku . Administrasi pertanahan merupakan bagian dari administrasi negara, karena administrasi pertanahan merupakan upaya pemerintah dalam menyelenggarakan kebijaksanaan di bidang pertanahan yang pelaksanaannya dilakukan oleh Badan Pertanahan Nasional (BPN) (Purwaningdyah dan Wahyudi, 2012).

Tujuan pemetaan partisipatif melalui mekanisme "sinden bertapa" selain untuk mendapatkan data spasial bidang tanah yang akurat dalam satu desa juga dalam rangka pelaksanaan pendaftaran tanah menuju tertib administrasi bidang pertanahan.

Tertib Administrasi Pertanahan adalah terciptanya suatu kondisi yang memungkinkan bahwa: a. Untuk setiap bidang tanah telah tersedia catatan mengenai aspek-aspek ukuran fisik, penguasan, penggunaan, jenis hak dan kepastian hukumnya, yang dikelola dalam sistem informasi pertanahan yang lengkap; $b$. Terdapat mekanisme prosedur/tatacara kerja pelayanan di bidang pertanahan yang 
sederhana, cepat dan murah, namun tetap menjamin kepastian hukum, yang dilaksanakan secara tertib dan konsisten; c. Penyampaian warkah-warkah yang berkaitan dengan pemberian dan pensertipikatan tanah telah dilakukan secara tertib, beraturan dan terjamin keamanannya (Murad, 1997).

Tujuan pendaftaran tanah yang Legal Cadastre adalah memberikan jaminan kepastian hukum hak atas tanah ; pemilik tanah akan dengan mudah membuktikan hak atas tanah yang dikuasainya. Karena proses akhir dari pendaftaran tanah yang legal cadastre akan diterbitkan dokumen tanda bukti hak oleh Pemerintah yang disebut dengan sertipikat tanah (Silviana, 2010). Dengan pendaftaran tanah, maka mereka yang memerlukan data tentang tanah dapat dengan mudah memperoleh keterangan tentang tanah yang akan diperoleh karena Kantor Pertanahan bersifat Terbuka untuk umum. Jaminan kepastian hukum tersebut ditunjukan terhadap kepastian mengenai objeknya yaitu tanah dan subyeknya yaitu pemilik tanah dan apa hak atas tanahnya. Kepastian mengenai objeknya yaitu meliputi letak tanah, batas-batas tanah, luas tanah. Sedangkan kepastian mengenai subjeknya yaitu siapa pemilik tanahnya serta apa jenis hak atas tanah, dan ada tidak beban-beban hak lain di atasnya (Harsono, 2010). Dalam rangka untuk mendapatkan kepastian tentang objek maka diperlkukan data kadastral melalui pengolahan di lapangan. Apabila sudah terbentuk tersedianya one map policy, maka pengolahan data tentang objek hak akan lebih jelas, aman dan mudah. Asas yang berlaku dalam pendaftaran tanah adalah Asas Aman, artinya untuk menunjukkan bahwa pendaftaran tanah perlu diselenggarakan secara teliti dan cermat sehingga hasilnya dapat memberikan jaminan kepastian hukum sesuai tujuan pendaftaran tanah.

Penataan tentang Struktur Hukum (legal structure), terkait dengan kelembagaan, dalam kelembagaan ini tentunyan yang harus diperhatikan adalah menghilangkan tumpang tindih kewenangan lembaga penegak hukum, menegaskan ruang lingkup tugas fungsi dan tanggung jawab lembaga penegak hukum, peningkatan kualitas SDM penegak hukum, meminimalisir pembiayaan yang non diskriminatif diantara lembaga penegak hukum, tertib koordinasi diantara lembaga penegak hukum, peningkatan kualitas dan nkuantitas terhadap sarana dan prasarana penunjang penegakan hukum serta penguatan pengawasan terhadap jalannya penegak hukum.

Kelembagaan dalam membangin sistem informasi bidang pertanahan, yang harus diperkuat adalah SDM dari lembaga BPN cq Kantor Pertanahan Kabupaten/Kota. 
BPN mempunyai kewenangan yang otonom dalam pelaksanaan pendaftaran tanah, karena lembaga yang diberi kewenangan untuk menerbitkan dokumen tanda bukti hak sebagai hasil pendaftaran tanah adalah Kantor Pertanahan. Namun SDM Kantor Pertanahan belum memadai dalam meningkatkan terbentuknya Sistem Informasi bidang Pertanahan yang akurat, karena selain minimnya SDM, juga pemahaman SDM tentang tugas kerja masing-masing bidang yang masih tumpang tindih. Yang perlu diperhatikan dalam kelembagaan hukum maka diperlukan jumlah petugas ukur yang tersertifikasi, karena masih minimnya jumlah petugas ukur di setiap Kantor Pertanahan, hal ini terkait dengan pemetaan bidang tanah dalam rangka pendaftaran tanah secara PTSL yang tentunya akan memerlukan waktu dan tenaga yang tidak sedikit.

Penataan Budaya hukum, yaitu melalui penyuluhan hukum dalam mengembangkan partisipasi masyarakat dalam pelaksanaan pendaftaran tanah. Peningkatan kesadara hukum masyarakat dalam pelaksanaan pendaftaran tanah merupakan keniscayaan, sehingga kegiatan penyuluhan dan pelatihan tentang pendaftaran tanah perlu selalu ditingkatkan. Kedepan apabila PTSL sudah berjalan dipadukan dengan pemetaan partisipatif dengan Sinden Bertapa, maka kualitas dan kuantitas tentang hasil pendaftaran tanah akan tercapai sehingga terwujudnya kebijakan satu peta dan terdaftarnya seluruh bidang atan akan tercapai. Demikian juga perlindungan hukum bagi pemegang sertipikat juga akan terwujud kepastiannya agar pemilik tanah tidak akan lagi rentan terhadap gugatan dari pihak ketiga. Dan untuk lebih memberikan kepastian hukum lagi, maka konsep tentangstelsel publikasi sudah dapat mengarah ke stelsel publikasi positif dalam penyelenggaraan pendaftaran tanah.

\section{Simpulan}

1. Mekanisme "Sinden Bertapa" di Desa Trisari Kecamatan Gubug, Kabupaten Grobogan dan pelaksanaan Pendaftaran Tanah Sistematik Lengkap (PTSL) adalah melalui metode pemetaan partisipatif yang menempatkan masyarakat sebagai bagian dari salah satu proses pemetaan desa bersama pemerintahan kabupaten sebagai pengkoordinasi wilayah, dan Kantor Pertanahan Kabupaten grobogan sebagai perencana dengan penyediaan Peta Citra sebagai dasar pelaksanaan pemetaan partisipatif.

2. Upaya membangun sistem informasi untuk mewujudkan satu peta Pendaftaran Tanah menuju tertib administrasi pertanahan apabila dikaji 
dengan Teori Sistem Hukum dalam penataan terhadap substansi hukum bahwa tujuan dari pendaftaran tanah adalah memberikann jaminan kepastian hukum (rechts cadastre) hak atas tanah dan perlindungan hukum kepada pemegang atau pemilik hak atas tanah sebagaimana ditentukan dalam Pasal 19 UUPA dengan peraturan pelaksanaannya. Tujuan akan kepastian hukum dan perlindungan hukum dalam kepemilikan tanah akan terwujud apabila Administrasi bidang Pertanahan sudah tertata dengan rapi dan tertib. Perlu dibenahi tata kerja Kantor Pertanahyan karena masih minimnya SDM untuk pelaksanaan pemetaan (juru ukur) dan kualitasnya masih rendah juga pemahaman SDM tentang tugas kerja masing-masing bidang yang masih tumpang tindih. Penataan Budaya hukum, yaitu melalui penyuluhan hukum dalam mengembangkan partisipasi masyarakat dalam pelaksanaan pendaftaran tanah. Peningkatan kesadara hukum masyarakat dalam pelaksanaan pendaftaran tanah merupakan keniscayaan, sehingga kegiatan penyuluhan dan pelatihan tentang pendaftaran tanah perlu selalu ditingkatkan.

\section{Saran}

1. Mekanisme "Sinden Bertapa" melalui pemetaan partisipasif menghasilkan produk yang sudah baik, seyogyanya mekanisme yang demikian tetap terus dikembangkan di wilayah kabupaten lainnya di seluruh Idonesia mungkin dengan nama yang berbeda melalui pemberdayaan masyarakat desa tentunya dukungan kerja sama dari Pemerintah Daerah sangat diperlukan .

2. Kantor Pertanahan sebagai pelaku utama dalam pelaksanaan pemetaan parisipatif seyogyanya terus meningkatkan SDM agar tujuan dari diperolehnya Peta Tunggal (One Map Policy) segera terwujud untuk penyamaan persepsi bagi semua pihak dalam memandang ruang kebumian.

\section{DAFTAR PUSTAKA}

Alamsah, Danang D. 2012. “Administrasi Pertanahan", Modul Universitas Terbuka, Tanggerang : Penerbit UT Bappenas, Kajian Persiapan Perubahan Sistem Pendaftaran Tanah Publikasi Positif di Indonesia, Jakarta : Direktorat Tata Ruang Dan Pertanahan Kemnetrian Perencanaan Pembangunan Nasional, Tahun 2016 Fahmi, Mansur. 2016. Peningkatan Kualitas Dan Kuantitas Data Base 
Pertanahan Melalui Kegiatan

Pemetaan Partisipatif Di Kabupaten

Grobogan, Badan Pertanahan

Nasional, Kantor Pertanahan

Kabupaten Grobogan, 2016

Harsono, Boedi. 2010, Hukum Agraria Indonbesia, Hukum Tanah Nasional : Sejarah Pembentukan Undang-

Undang Pokok Agraria, Isi dan

Pelaksanaannya, Jakarta : Universitas

Trisakti

Murad, Rusmadi. 1997. Administrasi

Pertanahan: Pelaksanaan Dalam

Praktik, Bandung: Mandar Maju

Purwaningdyah dan Agus Wahyudi,

"Konsep Dasar Administrasi dan
Administrasi Pertanahan", Modul 1, http://www.pustaka.ut.acid, Tahun 2012

Saleh, HS, Mjuh Ikhsan dan Hamzah Halim. 2009. Politik Hukum Pertanahan, Konsepsi Teoritik Menuju Artikulasi Empirik, Makassar: PuKAP

Silviana, Ana. 2012. Teori dan Praktek Pendaftaran Tanah, Semarang: Universitas Diponegoro Press.

Soeradji dan Nyoman Guntur, ID. 2007. "Pendaftaran Tanah", Modul, Yogyakarta: STPN Press.

Soekanto, Soerjono, Pendekatan Sosiologi Terhadap Hukum, 1988, Jakarta : Bina Aksara 